ISCKMC 2020

International Scientific Congress «KNOWLEDGE, MAN AND CIVILIZATION»

\title{
ORGANIZATIONAL AND PEDAGOGICAL CONDITIONS FOR PROFESSIONALLY ORIENTED TRAINING OF COMMUNICATION SPECIALISTS
}

\author{
Lidiia Mihajlovna Semenova (a)*, Oskar Yakovlevich Goykhman (b), \\ Liubov Markovna Goncharova (c) \\ * Corresponding author
}

(a) St. Petersburg State University of Economics, 21, Sadovaya Str., St. Petersburg, Russia, lidia_sem@mail.ru (b) Russian New University 326/300, 22 Radio Str., Moscow, Russia, aan1234569@yandex.ru

(c) Pushkin State Russian Language Institute Ac. 6, Volgin str., Moscow, Russia,1mg2015@yandex.ru

\begin{abstract}
The article deals with a problem relevant to the modern labour market - the professionally-oriented training of highly qualified communication specialists. The introduction of professional standards of specialists is now considered as a parameter of their qualifications necessary for performing a specific type of professional activity. The research is based on the integrative competency-based and professionological approaches and principles. The article is aimed to analyze the requirements of the labour market for university graduates and to offer a set of organizational and pedagogical conditions for professionally-oriented training of communication specialists. The study was conducted based on three universities in Moscow and Saint Petersburg. After analyzing the current competitive labour market and employer's requirements, the authors identified the barriers and interferences for university graduates in employment, as well as the problems in the training communication specialists. In the study, the authors revealed the increase in competition and demand for the new professions, including the sphere of business communication. To solve the problem, the authors proposed the introduction of a set of organizational and pedagogical conditions. The innovative nature of the study consists of the synergy of traditional and innovative pedagogical modelling and designing, which provides for the need for qualification requirements in the training of a specialist and the formation of professional competencies. The assessment of the results showed a positive dynamics of the studied process and confirmed the effectiveness of the complex of organizational and pedagogical conditions for professionally oriented training of communication specialists.
\end{abstract}

Keywords: Communication, professionally-oriented training, professional competence 


\section{Introduction}

The transformation of the socio-economic sphere of the society changes the approaches to higher education, actualizes the issues of innovative and "breakthrough" educational technologies focused on the profession. The normative documents in the field of higher education and the review of foreign literature focus on the quality training of highly qualified specialists who are capable of professional mobility in modern conditions (Peters \& Humes, 2003). In 2016, the Law of the Russian Federation on mandatory application and implementation of professional standards at enterprises entered into force, obliging all employers to apply them since 2020. The professional standard is interpreted as a professional qualification parameter that is necessary for performing a specific type of professional activity. Nowadays not all professional standards of specialists in the sphere of communication have been developed. The content of the professional standard is expected to include three areas of its application: for universities, professionals and employers. Universities must develop the educational standards and syllabi that correlate with the requirements of the labour market. The professional standards will help employers formulate the requirements for specialists and assess the level of professional competence. The professional standard will help the specialist to correlate the acquired professional competence at the university with the requirements of the labour market and a specific employer. All these factors influence the processes of modernization of higher education and the search for new organizational and pedagogical conditions for the formation of professional competence of graduates, prove the relevance of the current research (Dmitrenko, 2011; Rozhdestvenskaya \& Zhavoronok, 2018).

\section{Problem Statement}

Communication training is the basis for graduates in many fields: journalism, advertising and PR, philology, political science, etc. At the same time, there is a contradiction between the requirements of society, the labour market and the lack of development of the main provisions of professionally-oriented training of graduates of communication specialities at the university. The employers note a significant gap between the university training, based mainly on theory, and the practical aspects of a specific professional activity. The results of the study showed that the level of readiness for professional communication in future specialists does not correspond to the modern requirements of social services procurement. Some problems in training communication specialists were identified:

- the deformation of the value system leads to a decrease in the quality of education and the need to rethink the value orientations of students;

- the former cognitive and information system of higher education, which has lost its relevance in modern conditions, requires the modernization of the content of education and the search for new, more effective technologies for training specialists in the sphere of communications;

- the problem of professional development of the future specialist in the sphere of communication is becoming more and more urgent in line with the changing requirements of the labour market and employers;

- the insufficient practical training of university graduates requires time for its adaptation and "completion" in real working conditions; 
- the lack of professional standards of a specialist in the sphere of communication and the systematization of employer's requirements for young professionals in the sphere of communication give rise to the heterogeneity of requirements for graduates in employment.

The question has emerged - how to organize an effective professionally oriented training of communications specialists at the university? The innovative aspect of the task consists of the synergy of the traditional and innovative pedagogical modelling and designing, which provides for the need for qualification requirements in the training of a specialist and the formation of professional competencies. The strategic direction of the suggested invention is a preparatory course for graduates to master professional communicative competence.

The research was conducted at the Saint Petersburg State University of Economics, the Russian New University (Moscow), and the Pushkin State Institute of Russian language (Moscow) with the participation of 316 students, 12 teachers, and 57 practitioners.

\section{Research Questions}

The theoretical and methodological basis of the research is the integrative competence concept and the professionological approach to the training of communication specialists. The integrity is implied by the inter-subject relationships in the content of education; taking into account the fundamental and applied knowledge of communication-oriented subjects; the form of self-organization, self-reflection and self-correction by the students' quasi-professional activities; the level of professional development in assessing the effectiveness of professional training. With regard of the competence approach to the graduates' preparedness level for work, the professional competence is a comprehensive characteristic of specialist training quality, combined with the ability to target and informed application of complex knowledge and skills in various professional situations.

The integrative competence approach is not an alternative to the cognitive and information approach, but intensifying and enhancing it, and the result of the training is a professional competence or high-level readiness for effective professional activity (de Wit, 2019; Zeer et al., 2020).

The professionological approach is based on the concept of contextual and competence-based approaches, but its specificity is that the content of education must be systematically and purposefully saturated with the professionological knowledge, which as a result improves the quality of education. The approach focuses on the following principles: transformation and integration of didactics with practice and professional environment; facilitation; interactivity; independence and self-education, self-control; and reflection.

The professional approach implemented in the educational process helps:

- to determine the professional field of activity of communication specialists;

- to simulate quasi-professional activities in the classroom;

- to develop professional competencies, practical skills, manual skills and abilities;

- to create a collaboration of future specialists and practitioners in the educational, practical, and foresight-projection activities;

- to optimize the processes of self-knowledge, self-development, and self-control. 
Thus, the integrative competence-based and professionological approaches and the principles to the training of a communication specialist helped to justify the aspects of professionally oriented training in higher education.

\section{Purpose of the Study}

The purpose of this article is to analyze the requirements of the labour market for the graduates (bachelors and masters) of communicative oriented directions and to define a set of organizationalpedagogical conditions of professionally oriented training of specialists of this sphere in higher education.

\section{Research Methods}

The applied research methods are the following: pedagogical experiment, observation of practical experience, survey of the graduates, teachers and employers, content analysis, document analysis.

\section{Findings}

The results of the analysis of the modern labour market and requirements for communication specialists have shown that in the era of globalization, the need for communication is becoming more acute. The new communication reality creates new professions that are not yet sufficiently studied, formed and officially registered. The applied content analysis showed that today in Russia, according to official data, there are five thousand professions, but according to unpublished data (the research by the Academy of Image Studies), there are 49 thousand of them. In the Unified Tariff and Qualification Reference Book, there are more than seventy thousand names of professions and positions available in Russia (the list for the positions of managers, specialists and employees, and for jobs and professions of workers). Their number is constantly growing in world practice. In professional communication, there have emerged such professions as a creator, a brand manager, a media buyer, a social media manager, a facilitator, a mediator, a reputation manager, an image-maker, a performance manager, a strategic communications specialist, etc. This fact explains that the need for specialists in communication-oriented professions is rapidly increasing in the world.

The labour market in the modern world is subject to a process of turbulence due to the changes in socio-economic conditions, the digitalization of society, and the modernization of higher education, which generate a lot of problems and new algorithms for solving them (Edmiston, 2014; Swanson \& Schneider, 2013). The analysis of the labour market shows an increase in competition, growth of demand for relatively new professions, including in the sphere of business communication (Strauss, 2017). The data from the recruitment company Manpower Group (2020) showed the increased competition for highly qualified specialists $-35 \%$ of employers are now looking for them around the world, and this is the largest percentage in recent decades, and $54 \%$, which is a record number of companies in the world, faced with a lack of talent. The research carried out by the Internet recruitment company HeadHunter

(HH) conducted for the past three years also shows the demand for highly qualified specialists in the sphere of communications and the key requirements for young professionals: initiative, high 
responsibility, ability to work in a team, etc. The research carried out by Harvard University, the Carnegie Endowment, and the Stanford Research Center conducted 100 years ago showed that the labour market and employers had a great need for supra-professional, universal skills (soft skills) of specialists, on which $85 \%$ of their effective and successful work depends (Mann, 1918).

These skills include interpersonal and business communication skills, self-management, project management, business ethics, adaptability, attractiveness, assertiveness, leadership skills, the ability to solve goals and achieve the desired result, and many others (Zabojnik, 2018). The research carried out by the National Association of Colleges and Employers (USA) and Google confirms the current demand for communication skills putting them into the top positions (Strauss, 2017).

Our research conducted among practitioners in Saint Petersburg (33 people) and Moscow (24 people) showed that they want to see responsible, mobile, open to new knowledge specialists who are ready for self-improvement and self-development, for online learning, disciplined, executive, as well as sociable and creative.

According to the job search portal "Rabota@Mail.ru", 86 \% of graduates of Russian universities with diplomas in Humanitarian Sciences cannot get a job in their speciality, including the reason of insufficient professional competence. There is also evidence that at present, most graduates in the Russian labour market do not work in the speciality obtained at the University (RIA Novosti, 2019). Thus, a paradox is stated - on the one hand, there is a demand for qualified personnel with good language and communication skills, on the other hand, the university graduates can not find a job in their speciality. Employers explain this contradiction by the fact that they are approached by a lot of certified specialists, but most of them do not meet the requirements of the modern labour market, do not have a high level of professional and universal competencies. The employers are now waiting for a generalist who can present high-quality work and results.

It can be concluded that the perception of employers and young professionals about the requirements of the modern labour market is generally the same, but they differ in some parameters. Due to the changes in the labour market, the requirements for higher education institutions on the issue of personnel training, the formation of professional and universal competencies, and supra-professional skills are also changing. Therefore, it is time to modernize and upgrade the professional training of communication specialists (Keyek-Fransen, 2018).

As a result of the research, a set of organizational and pedagogical conditions affecting the professional development of future specialists, attitudes to the profession, the accumulation of practical experience, and professional improvement have been identified.

1. Development of a value-based educational environment focused on the formation of professional competence of a future communication specialist. The educational environment is suggested to be interpreted as a unity of multi-factor systems, models, conditions and opportunities for the formation of professional competence, designed in connection with the needs of society and the state, with the requirements of the labour market. The value-based educational environment at a university is a personal development environment, which is a space that includes educational, scientific, cultural, ethical, professional and other values, where the conditions for the professional development of the future specialist's personality are created. The organization and formation of the educational environment are 
now one of the trends in the modernization and evolution of the content of higher education. Many scientists believe that without creating a special educational environment, the activity to form professional competencies may be ineffective. The professionalization process of the value educational environment at a university is designed to determine the student's attitude: "I am a sought-after specialist", who is ready for professional communication and able to join any professional community. Saturating the educational environment with cases, situational tasks, practical projects, problem tasks forms a value attitude to their future profession and allows future specialists to quickly adapt to the professional sphere in the future.

2. Modernization of the content of training courses to focus on the profession in the sphere of communication. The formation of professional competence of future communication specialists in higher education requires the organization of such training that ensures the transition of cognitive activity to professional. At the same time, the strategy and tactics of training, goals and motives, technologies, teacher-student interaction, tools, the content of academic subjects, including for the online format (Nadeina et al., 2019), and results of the activities should be changed. The organization of an educational facilitator, methodological assistance in the formation of professional competencies, and an emphasis on learning rather than teaching - all this makes the learning process more effective.

3. Professionalization of extracurricular activities of students and the inclusion of practitioners in the formation of professional competencies. Professionalization should be implied in all types and forms of extracurricular activities of students to transfer them to higher levels of quasi-professional activity. The inclusion of representatives of the professional community in this process - practitioners, graduates, and employers - will strengthen professional contacts, form corporate cooperation, facilitate practical training, help identify problems and topics for final qualifying work, and show examples of professional skills. The collaboration of students and professionals under the supervision by the teachers contributes to the consolidation and application of knowledge, skills and abilities in practice, gives the training a professional character and leads to the achievement of the planned result (Dzobelova et al., 2019).

One of the requirements for high-quality professional training of future communication specialists is the involvement of each of them into active cognitive activity, the application of their knowledge in practice and a clear understanding of where, how and for what this knowledge will be applied. Creating a chain of educational activities, project activities, a favourable psychological climate in the student group, an atmosphere of trust and mutual understanding, and communicative comfort are also conditions for success in professional training.

To test the effectiveness of these conditions, we conducted a pedagogical experiment in which four groups of students were formed, three experimental (EG) ones and a control (KG) one. In EG-1, the first organizational and pedagogical condition was introduced, in EG-2, the second and third conditions were introduced, in EG-3, the entire set of conditions was introduced, and in CG, the training took place in the usual education mode. Three levels of formation of professional competence of students at the initial and final stages of the experiment were identified (Table 01). 
Table 1. Levels of formation of students' professional competence at the beginning and the end of the experiment

\begin{tabular}{|c|c|c|c|c|c|c|c|c|c|}
\hline \multirow{3}{*}{ Group } & \multirow{3}{*}{ Stage } & \multicolumn{6}{|c|}{ Levels } & \multirow{3}{*}{ Avg. } & \multirow{3}{*}{$\mathrm{C}_{\text {eff }}$} \\
\hline & & \multicolumn{2}{|c|}{$\begin{array}{l}\text { Adaptive and } \\
\text { reproductive }\end{array}$} & \multicolumn{2}{|c|}{$\begin{array}{l}\text { Search and } \\
\text { heuristic }\end{array}$} & \multicolumn{2}{|c|}{$\begin{array}{c}\text { Professional and } \\
\text { creative }\end{array}$} & & \\
\hline & & Quantity & $\%$ & Quantity & $\%$ & Quantity & $\%$ & & \\
\hline EG-1 & the beginning & 57 & 77 & 12 & 16 & 5 & 6 & 1.13 & 1.64 \\
\hline 74 people & the end & 22 & 29 & 39 & 52 & 15 & 20 & 1.45 & 0.81 \\
\hline EG-2 & the beginning & 54 & 65 & 19 & 22 & 10 & 12 & 1.31 & 0.74 \\
\hline 83 people & the end & 19 & 22 & 35 & 42 & 29 & 34 & 2.08 & 1.16 \\
\hline EG-3 & the beginning & 55 & 63 & 20 & 23 & 11 & 12 & 1.42 & 0.8 \\
\hline 86 people & the end & 3 & 3 & 32 & 37 & 49 & 56 & 2.61 & 1.46 \\
\hline CG & the beginning & 25 & 34 & 33 & 45 & 15 & 20 & 1.76 & - \\
\hline 73 people & the end & 21 & 28 & 45 & 61 & 15 & 20 & 1.79 & - \\
\hline
\end{tabular}

The effectiveness of implementing organizational and pedagogical conditions was tested using the $\mathrm{X} 2$ criterion of $\mathrm{K}$. Pearson. As a result, it was convinced that the level of professional competence of future specialists in EG-3, where the whole complex of organizational and pedagogical conditions was implemented, is significantly higher, which indicates their effectiveness.

Verification of these conditions confirmed that each of them contributes to the formation of professional competence of future specialists, but only combined they give the best effect. Thus, it should be mentioned that the proposed set of organizational and pedagogical conditions contributes to the formation of professional competence of the future communication specialists and helps to fulfil the social order for the training of highly qualified specialists. These conditions have the properties of necessity and sufficiency, but these properties are conditional.

\section{Conclusion}

In conclusion, we found that the modern labour market requires highly qualified specialists who are ready to effectively carry out communication activities and possess universal skills. Higher education in Russia and abroad is looking for innovative approaches, technologies, and conditions for professionally-oriented training of specialists in the sphere of communications. The integrativecompetence and professionological approaches to training specialists contribute to the formation and improvement of the human capital expected by the labour market during the period of study at a university. The complex of organizational and pedagogical conditions we have modelled has a positive impact on the professional development of future specialists.

\section{References}

de Wit, H. (2019). Evolving Concepts, Trends, and Challenges in the Internationalization of Higher Education in the World. Ed. Studies Moscow, 2, 8-34.

Dmitrenko, T. A. (2011). Professionally oriented training of students in the system of higher language education. Personality. Culture. Society. Int. J. of Soc. and Human Sci., XIII(4(67-68)), 325-330.

Dzobelova, V., Yablochnikov, S., \& Semenova, L. (2019). Practical Application Analysis of Information and Communication Technologies in the Socio-Economic Sphere. In Proc. of Communicative Strategies of the Information Society (CSIS'19). ACM. 
Edmiston, D. (2014). Creating a Personal Competitive Advantage by Developing a Professional Online Presence. Market. Ed. Rev., 24, 21-24.

Keyek-Fransen, D. (2018). Practices for Student Success: From Face-to-Face to At-Scale and Back. Ed. Stud. Moscow, 4, 116-138.

Mann, C. R. (1918). A Study of Engineering Education. Bull. Number Eleven. New York City, 139.

Manpower Group (2020). Manpower Group Russia \& CIS. https://manpowergroup.ru/media/ research/chego-xotyat-rabotniki-kak-privlech-talantyi.html

Nadeina, T.M., Goykhman, O.Y., Goncharova, L.M, Koshlyakova, M.O. (2019). Textbook During Education Virtualization. REVISTA INCLUSIONES, 6, 193-200.

Peters, M. A., \& Humes, W. (2003). Education in the Knowledge Economy. Policy Futures in Ed., 1(1), 119.

RIA Novosti. (2019). https://ria.ru/20190902/1558146808.html

Rozhdestvenskaya, E. M., \& Zhavoronok, A. V. (2018). The Subjective Assessment of Organizational and Pedagogical Conditions of a Bachelor's Project Work. Bull. of Tomsk State Univer., 434, 167177.

Strauss, V. (2017). The surprising thing Google learned about its employees and what it means for today's students. https://www.washingtonpost.com/news/answer-sheet/wp/2017/12/20/

Swanson, J.L., Schneider, M. (2013). Minnesota theory of work adjustment. In S. D. Brown \& R.W. Lent (Eds.), Career Development and Counseling: Putting Theory and Research to Work (2nd ed., pp. 2953). Wiley.

Zabojnik, R. (2018). Personal Branding and Marketing Strategies. Europ. J. of Sci. and Theol., 14(6), 159-169.

Zeer, E. F., Tretyakova, V. S., \& Zinnatova, M. V. (2020). An Innovative Model of Socio-Professional Development of the Student's Personality. Ed. and Sci., 22(3), 83-115. 